\title{
Current controversies in the Caledonides
}

\author{
P. W. G. TANNER ${ }^{1} \&$ B. J. BLUCK ${ }^{2}$ \\ ${ }^{1}$ Division of Earth Sciences, Gregory Building, University of Glasgow, Glasgow G12 8QQ, UK \\ ${ }^{2}$ Department of Geography, University of Glasgow, Glasgow G12 8QQ, UK
}

Keywords: Proterozoic, Scotland, orogenesis, tectonics, geochronology.

This set of papers arose from a Discussion Meeting held in the Department of Geology \& Applied Geology, University of Glasgow, on 9-10 September 1997. The aim of the Meeting was to review the progress which had been made in resolving some of the more controversial aspects of the pre-Silurian Caledonide geology of the British Isles and Scandinavia. It was also held to mark the retirements of two well-known Caledonide geologists: Professors Bernard Leake and Donald Ramsay. There were 34 talks and poster contributions, and the meeting was attended by over 100 people. We would like to thank our colleague Tim Dempster for helping to convene and organize the meeting.

It was fitting that the Meeting should be held in the Gregory Building, which was named after the Glasgow Professor who not only pioneered work on rift tectonics and regional uplift in Africa, but also wrote a perceptive book on 'Dalradian Geology' (Gregory 1931). In this work, Gregory pointed out that his observations were made over a period of 25 years, being made on 'recreational weekends', and mainly in winter 'when the ground is less obscured by vegetation and the Highland mountains most attractive': an approach motivated by a spirit of enquiry, and very productive, but one which would be out of step with current research strategies.

We would like to dedicate this set of papers to Mark Piasecki who died on 13 June 1999. Mark was the first person to draw attention to major problems concerning the relationship between the Moine and Dalradian Supergroups. His careful field observations, thoughtfully linked to focused radiometric dating in collaboration with Otto van Breemen, confirmed the reality of a 'c. $750 \mathrm{Ma}$ event' in some of these rocks. Mark would have derived a wry satisfaction from reading the papers presented here on the Central Highlands.

\section{The Caledonian fold belt}

This thematic set of nine papers focuses upon major problems in both the older part of the Caledonian fold belt of Scotland found north of the Midland Valley terrane (Fig. 1), and in the Dalradian inlier of Connemara, western Ireland. Although the Connemara inlier is located within the inferred continuation of the Midland Valley of Scotland, the Dalradian rocks of the inlier are linked stratigraphically and structurally with the Scottish Dalradian. The timing of events in Connemara is therefore of direct relevance to an understanding of the timing of events in Scotland, and of the Grampian orogeny in general.

Although the Scottish Caledonides only occupy a narrow zone some $70-200 \mathrm{~km}$ across (Fig. 1), they have been a fertile ground for the growth of new ideas and techniques for over a century. Some of the major advances in basement geology have been made here. These include the classical demonstration of a major overthrust, the Moine Thrust (Peach et al. 1907); the establishment of Barrovian regional metamorphic zones by Barrow (1893); pioneering structural and stratigraphical syntheses by Bailey and his co-workers (Bailey \& McCallien 1937, and references therein), including the early use of way-up structures in metamorphic rocks (Bailey 1930); the first demonstrations of polyphase deformation by Clough (in Gunn et al. 1897) and Ramsay (1957); and the introduction of the concept of structural facing by Shackleton (1958).

Despite this pedigree, and decades of detailed field and laboratory work which have earned the Scottish Caledonides the accolade of being one of the most intensively studied fold belts in the world, we find that we are still unable to answer the most elementary questions, such as:

- when were the major rock units deposited?

- have they been affected by one, two, or even three orogenic events?

- how old are these orogenies?

- and, if exotic terranes are involved, how many were there, and when did amalgamation take place?

Thus the Caledonides are currently the focus of surprisingly fundamental disputes. At the heart of these problems is the lack of chronostratigraphical control; the difficulty in recognizing orogenic unconformities in rocks which have subsequently been highly deformed and metamorphosed; and the difficulty in relating radiometric mineral ages to structural and metamorphic events. Our present inability to resolve these conflicts in the Caledonides seriously questions our understanding of the evolution of other fold belts that are less well documented, and that also involve Precambrian rocks. Similar problems associated with recognizing and defining an orogenic event have been recently reviewed by Gray \& Foster (1997), with respect to the Lachlan fold belt in Eastern Australia.

In the papers making up this thematic set, the usage of certain terms is as follows: the Grenville Orogeny refers to the 1000-1100 Ma event; the Knoydartian Orogeny (sensu Bowes 1968) [synonym: Morarian (Lambert 1969)] refers to the 800-850 Ma event; the Grampian Orogeny (comparable with the mid-Ordovician Taconic Orogeny in the Applachians) refers to the early Ordovician event (c. 470-490 Ma) (following the original definition of Lambert \& McKerrow 1976); and the Caledonian Orogeny refers loosely to Ordovician to Silurian deformation of these sequences.

\section{Current models for the Caledonides}

Four main stratigraphical units are involved, which from north to south in Scotland (Fig. 1 \& Table 1) are as follows:

(1) The Moine Supergroup in the Northern Highlands.

(2) A 'basement group' (Glen Banchor and Dava successions) found in the Central Highlands immediately south of the Great Glen Fault. 


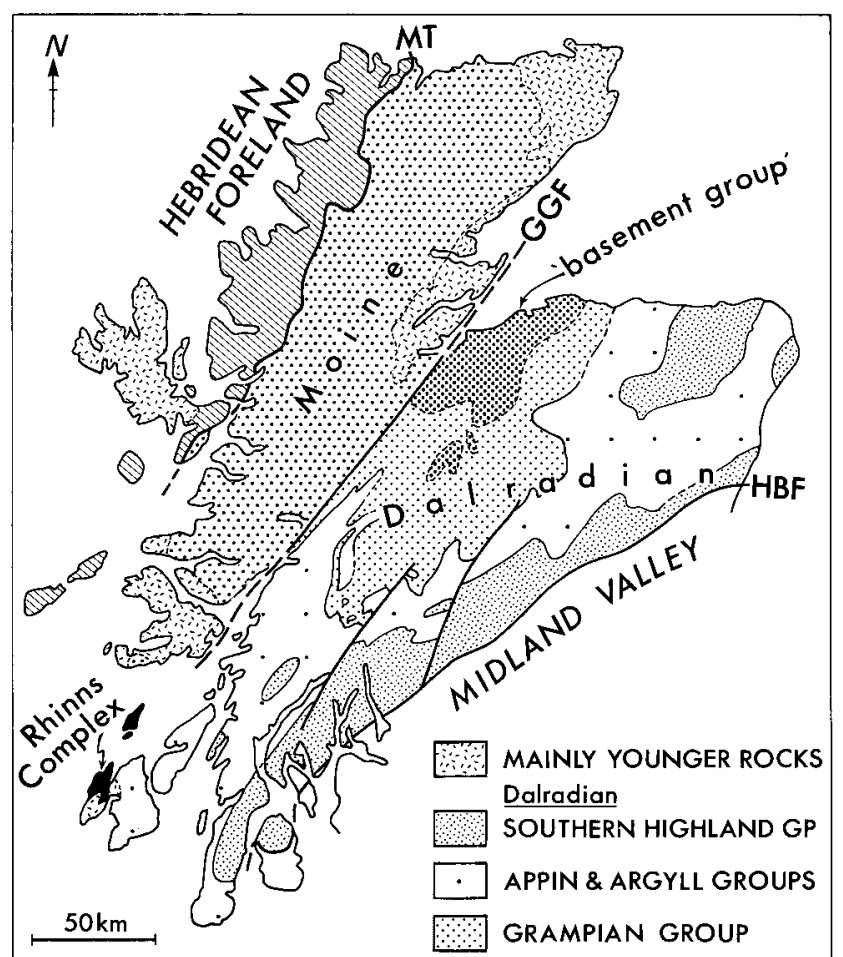

Fig. 1. Geological map showing the main lithostratigraphical units in the Scottish Caledonides, with neighbouring crustal blocks. Igneous intrusions and small areas of younger sediments are not shown separately; those forming larger areas are ornamented. The Hebridean foreland (cross-hatched) includes the crystalline Lewisian Complex and the Moine Thrust Zone. The Moine outcrop (heavy stipple) includes areas of Lewisianoid basement rocks. HBF, Highland Boundary Fault; GGF, Great Glen Fault; and MT, Moine Thrust.

Table 1. Relations and ages of the main lithostratigraphical units in the Scottish Caledonides referred to in this paper

\begin{tabular}{|c|c|c|}
\hline Highland Border Complex & \multirow{2}{*}{ uncertain relationship- } & Ordovician \\
\hline Keltie Water Grit Formation & & \multirow[t]{3}{*}{ Cambrian } \\
\hline Southern Highland Group & \multirow{4}{*}{ DALRADIAN } & \\
\hline Argyll Group & & \\
\hline Appin Group & & \multirow{3}{*}{ Neoproterozoic } \\
\hline Grampian Group & & \\
\hline \multirow[t]{4}{*}{ 'basement group' } & & \\
\hline & MOINE & Neoproterozoic \\
\hline & RHINNS COMPLEX & Mesoproterozoic \\
\hline & LEWISIAN & $\begin{array}{l}\text { Archaean- } \\
\text { Palaeoproterozoic }\end{array}$ \\
\hline
\end{tabular}

(3) The Grampian Group. This group includes all of the rocks which lie stratigraphically between the 'basement group' and the base of the Appin Group in the Central Highlands. It is normally taken to be part of the Dalradian Supergroup (i.e. Gibbons \& Harris 1994) but, for the purposes of discussion, is considered separately here.

(4) The Dalradian Supergroup of the Southwest and Grampian Highlands, which comprises the Appin, Argyll, and Southern Highland Groups.

The Highland Border Complex, which crops out along the line of the Highland Boundary Fault in Scotland (Fig. 1), is not included in this review as no new work on the complex was presented at the meeting.

As a focus for discussion, we can identify three generalized models which have been proposed by different authors (but not necessarily in this form) to explain the relationships between various of these four units within the Scottish and Irish Caledonides.

(A) The simplest model is that espoused by Soper \& England (1995) in which the Moine, 'basement group', Grampian Group, and Dalradian units were deposited in a southwardpropagating sequence of rift basins, which were then deformed during a single orogenic event of early Ordovician age (the Grampian orogeny). U-Pb ages of $800-850 \mathrm{Ma}$ from metaigneous rocks and migmatites within the Moine and 'basement group' rocks are considered to relate to high heat flow associated with the syn-depositional rifting events (Soper \& England 1995; Soper \& Harris 1997). In this model, the Dalradian sequence is considered to continue up into the Cambrian, and even possibly the Lower Ordovician (Molyneux 1998). Detritus from the uplifted orogenic welt is inferred to be present in the rocks of Caradocian age in the Midland Valley and the Southern Uplands of Scotland (Hutchison \& Oliver 1998).

(B) In the second model, Neoproterozoic (800-850 Ma) orogenesis affected both the Moine and 'basement group' rocks. The Dalradian sequence, which includes Grampian Group rocks at its base, continued up into the Lower Cambrian, and was deformed for the first time during the Ordovician. A so-far undectected orogenic unconformity is required between the Dalradian and underlying rocks. The Highland Border Complex is divided into a Cambrian part continuous with the Dalradian (Harris 1962; Tanner 1995), and an Ordovician part which was probably exotic.

(C) According to this model, the Moine, 'basement group', and all of the Dalradian rocks stratigraphically below the Southern Highland Group, were affected by two separate contractional orogenic events, during the Neoproterozoic (800-850 Ma) and Ordovician (470-510 Ma). The Southern Highland Group was probably affected only by the Grampian event, and the Cambrian to Upper Ordovician rocks of the Highland Border Complex formed a separate exotic terrane which docked with the Dalradian block in late SilurianDevonian times (Bluck 1985).

\section{The present situation}

The focus of this brief review is upon the recent data, and especially that presented in this volume; the reader is referred to the individual papers for an historical background and for further details of the matters mentioned here.

\section{Moine Supergroup}

These rocks are generally considered to have an unconformable relationship to Archaean-Palaeoproterozoic Lewisian 
gneisses preserved as thrust slices east of the Moine Thrust in Sutherland (see Gibbons \& Harris 1994). However, Moine rocks may be allochthonous with respect to the $1.0 \mathrm{Ga}$ (Sanders et al. 1984) eclogite-bearing basement rocks seen farther south in the Glenelg inlier of the Western Highlands (Temperley \& Windley 1997). The maximum age of the Supergroup is defined by the youngest reported $\mathrm{U}-\mathrm{Pb}$ age on detrital zircon, namely $1005 \mathrm{Ma}$ (Kinny et $\boldsymbol{a l}$. this volume), and the minimum age by that of the Ardgour Gneiss at $c .873 \mathrm{Ma}$ (Friend et al. 1997). Most workers are agreed on the overall stratigraphy and structure of the Moine, but problems arise over the absolute timing of the various events.

A series of discontinuous sheets of S-type granite, associated with basic intrusions, cut the Moine rocks on a regional scale. They have been subsequently deformed and metamorphosed to form the West Highland (or Ardgour) Granitic Gneiss. At Glen Doe, where these igneous rocks occur in the regional 'flat belt' and were least affected by Caledonian deformation, they are accompanied by a suite of MORB-like basic dykes. Millar (this volume) has obtained an age of $873 \pm 6 \mathrm{Ma}$ from a gabbro body which cuts the granite gneiss protolith in this area. He concludes that, on balance, the entire igneous suite was emplaced in a pre-tectonic, extensional regime. However, this conclusion has to be reconciled with an identical $\mathrm{U}-\mathrm{Pb}$ age on zircon of $873 \pm 7$ Ma obtained by Friend et al. (1997) from the Ardgour Gneiss, which these authors interpret (following Barr et al. 1985) as being the time of the contractional D1 (Knoydartian) deformation. These two conclusions are incompatible unless the intrusion, deformation, and early metamorphism of the igneous complex all took place within $13 \mathrm{Ma}$, i.e. within the maximum combined error on the two determinations. Participants in the Highland Field Workshops (Soper \& Harris 1997) concluded that the field evidence shows that the basic rocks cut the West Highland Gneiss, and that both were affected by all of the deformation phases affecting the Moine country rocks.

Two recent independent studies provide evidence for the existence and the age of the Knoydartian Orogenic event, long since considered to be $>750 \mathrm{Ma}$ in age by Piasecki \& van Breemen (1983). U-Pb dating of monazite from the Ardnish and Sgurr Breac pegmatites in Morar gave ages of $827 \pm 2 \mathrm{Ma}$ and $784 \pm 1 \mathrm{Ma}$, respectively (Rogers et al. 1998). These pegmatites were considered by Rogers et al. to have formed during shearing which accompanied garnet-grade regional metamorphism, following at least one episode of deformation. This structural interpretation has been challenged by the Highland Workshops (Soper \& Harris 1997) with respect to the Ardnish pegmatite, which they conclude pre-dates all of the deformational events at that locality. The second example is reported by Vance et al. (1998) who have obtained Sm-Nd ages of 820-790 Ma for garnet growth in the Moine rocks in the Morar area within $<17 \mathrm{~km}$ of the Ardnish locality. These authors conclude that the calculated $P-T$ conditions for garnet growth (with $P>11$ kbar), together with the inferred $P-T$ path, can only have resulted from crustal thickening during orogenesis. Taken together, these studies would appear to show that a major tectonothermal event took place in the Moine rocks at around $800 \mathrm{Ma}$ ago.

The effects of Grampian deformation and regional metamorphism have been confirmed in work reported here by Kinny et al., who have obtained $\mathrm{U}-\mathrm{Pb}$ ages on zircons of $461 \pm 13 \mathrm{Ma}$ and $467 \pm 10 \mathrm{Ma}$ from the migmatite complexes of Sutherland, previously considered to be of Precambrian age. These ages compare well with a concordant monazite age of $455 \pm 3 \mathrm{Ma}$ from the Ardgour Gneiss (Aftalion \& van Breemen 1980), and $455 \mathrm{Ma}$ for the timing of possible lead loss from zircons from the same body (Friend et al. 1997).

\section{'Basement rocks' and Grampian Group of the Central Highlands}

Considerable progress has been made over the past few years by geologists of the British Geological Survey in elucidating the stratigraphy and structure of the lithologically monotonous rocks which occur immediately southeast of the Great Glen Fault (Fig. 1). In this volume Smith et al. present a synthesis of this work and conclude that there is a stratigraphical break (but no tectonic discontinuity), between the 'basement group' (Glen Banchor and Dava successions), and the younger rift-controlled Grampian Group sediments. The rocks mapped as the 'basement group' are broadly equivalent to the former Central Highland Division of Piasecki (1980). Depositional environments are explored in more detail by Robertson \& Smith (this volume) who focus on basin geometry and the recognition of onlap of the Dalradian sequence on to basement 'highs', and the control that rift basin geometry has exerted upon the subsequent fold geometry and strain distribution in the Central Highlands of Scotland.

Previous work had indicated that there is structural and metamorphic continuity between 'cover' and 'basement' in this area (Lindsay et al. 1989), and Phillips et al. (this volume) explore this possibility in greater detail. They conclude that the same, progressive, D1-D2 structural events, accompanied by northerly-directed thrusting, affected the entire sequence from the basement rocks, through the Grampian Group, to the Appin Group. The prograde regional metamorphism reached kyanite grade, with pressures of 7-10 kbar.

In this volume, Highton et al. report an $\mathrm{U}-\mathrm{Pb}$ zircon age of $840 \pm 11 \mathrm{Ma}$ which is considered to date the D1 deformation in migmatized basement gneisses. Taken in conjunction with the U-Pb monazite ages of $c$. $800 \mathrm{Ma}$ which were reported by Noble et al. (1996) from pegmatites in late D2 shear zones which cut the 'basement group', these data provide the basis for a correlation with the $800-850 \mathrm{Ma}$ thermal event in the Moine rocks. Highton et al. describe slices of kyanite- and staurolite-bearing Grampian Group rocks from within the 'Grampian Shear Zone' which, according to Noble et al. developed some $800 \mathrm{Ma}$ ago. This observation supports Piasecki's original contention that the Grampian Group was affected by a Precambrian metamorphism.

\section{Dalradian Supergroup}

The Dalradian stratigraphy is well established, and most workers are agreed about the overall architecture, if not the kinematics, of the Dalradian block. There is a lithological, structural, and metamorphic transition from the Grampian Group to the Appin Group (Table 1), and no orogenic disconformity has been detected within the Supergroup, despite much searching in recent years. There has however been a problem since the turn of the century over defining the top of the unit, and Tanner \& Pringle (this volume) present new stratigraphical and petrographical evidence for including the upper Lower Cambrian rocks (509-517 Ma) at Callander, as part of the Dalradian succession. However, there are a few old $\mathrm{K}-\mathrm{Ar}$ and $\mathrm{Rb}-\mathrm{Sr}$ mica cooling ages (>480-500 Ma) from 
the Southern Highland Group (i.e. Dempster 1985) that are difficult to reconcile with this conclusion.

There are few reliable indications of the age of the Dalradian succession. They include the recent discovery from Islay of a metazoan Neonereites uniserialis, which is characteristic of terminal Neoproterozoic strata (Brasier \& McIlroy 1998); a single acritarch of Ordovician age from close to the top of the succession in Banffshire on the NE coast (Molyneux 1998); correlation of the Portaskaig Boulder Bed at the base of the Argyll Group and the overlying Bonahaven Dolomite, with the 650 Ma Varanger (630-590 Ma; Roberts et al. 1997) tillites and 'cap dolomite' from the North Atlantic region (Fairchild \& Harrington 1989); and the U-Pb zircon age of $595 \pm 4 \mathrm{Ma}$ from the Tayvallich Lavas (Halliday et al. 1989) In addition, the Ben Vuirich granite U-Pb zircon age of $590 \pm 2 \mathrm{Ma}$ (Rogers et al. 1989) provides a minimum age for the D2 deformation (Tanner \& Leslie 1994). When taken together, these disparate pieces of evidence constitute a good case for concluding that the upper part of the Dalradian succession, at least, was not affected by an $800-850$ Ma thermal event seen in the older portion.

Friedrich et al. (this volume) provide new $\mathrm{U}-\mathrm{Pb}$ ages on zircon, titanite, and monazite from igneous intrusions and calc-silicate rocks from the Dalradian of Connemara, western Ireland. From these data, together with recently published $\mathrm{U}-\mathrm{Pb}$ ages on zircon of $474.5 \pm 1 \mathrm{Ma}$ and $470.1 \pm 1.4 \mathrm{Ma}$ from the metagabbro intrusions, and an $\mathrm{U}-\mathrm{Pb}$ age on xenotime of $462.5 \pm 1.2 \mathrm{Ma}$ from the post-D4 Oughterard Granite (Friedrich et al. 1999a), these authors conclude that the Grampian orogeny in western Ireland was a short-lived midOrdovician event, which took place between c. 475 and $463 \mathrm{Ma}$. The new data confirm that a discontinuous magmatic arc was active at about the same time in Connemara and Scotland, with gabbro intrusion in NE Scotland dated at c. $470 \mathrm{Ma}$ (Rogers et al. 1994), and granitic intrusions of 460-470 Ma age occurring in both regions (Tanner et al. 1997). However, all of the intrusive bodies and mineral assemblages that have been dated in Connemara are either synchronous with, or post-date, the D2 deformation, and the timing of the earliest events there remains enigmatic.

Finally, Soper et al. (1999) present a synthesis of the data from Scotland and western Ireland from which they conclude that the entire Dalradian succession, including the Grampian Group, has behaved as a stratigraphical and structural entity and was only affected by the Grampian event about $470 \mathrm{Ma}$ ago. They infer that the Grampian orogeny was a very short-lived Taconic-type arc accretion event.

\section{Some conclusions}

(1) Detrital zircons from the Moine, and inherited zircons from granitic intrusions in the Dalradian block (Pidgeon \& Compston 1992), show broadly the same Mesoproterozoic $\mathrm{U}-\mathrm{Pb}$ provenance ages $(1100-1800 \mathrm{Ma})$, and little or no Archaean input. These detrital ages support the thesis of Bluck et al. (1998) that the Hebridean foreland sequence in NW Scotland (Fig. 1) is exotic to the Caledonides. The older ages (1700-1800 Ma) are comparable with those reported from the Rhinns Complex (Fitches et al. 1996, and references therein).

(2) Both the Moine and Dalradian Supergroups were deposited after the Grenvillian (1000-1100 Ma) orogeny.

(3) The reality of an $800-850 \mathrm{Ma}$ event in the Moine and 'basement group' is now fully established, but its significance is still being debated. The current balance of evidence appears to favour the interpretation that a Knoydartian, contractional, orogenic event took place at this time in the Moine, and also affected the 'basement group' of the Central Highlands.

(4) It could be concluded from the new work reported here from the Central Highlands, together with the lack of evidence from anywhere in the Dalradian outcrop of a tectonic break separating the Grampian and Appin groups, is that the lower half of the Dalradian Supergroup has also been affected by the 800-850 Ma thermal event.

(5) Both the Moine and Dalradian Supergroups were deformed and metamorphosed during an Ordovician (Grampian) orogenic event.

(6) Many lines of evidence indicate that the upper part of the Dalradian succession ranges in age from late Proterozoic $(<650 \mathrm{Ma})$ to Cambrian $(509-519 \mathrm{Ma})$ in age, and has only been affected by the Ordovician (Grampian) orogenic event.

(7) The major dilemma that remains is that there is at present no evidence upon which to draw an actual dividing line between two Dalradian domains: one possibly affected by both Neoproterozoic (800-850 Ma) and Grampian orogenic events, and the other only by the Grampian event.

(8) The difficulties in resolving the stratigraphical and structural problems in the Caledonides appear to have arisen from the interaction between two orogenic events without a clear cover-basement relationship being preserved between the two groups of rocks in Scotland.

We thank N. J. Soper and R. A. Strachan for their perceptive reviews of the manuscript.

\section{References}

Aftalion, M. \& van Breemen, O. 1980. U-Pb zircon, monazite and Rb-Sr whole rock systematics of granitic gneiss and psammitic to semi-pelitic host gneiss from Glenfinnan, northwestern Scotland. Contributions to Mineralogy and Petrology, 72, 87-98.

Bailey, E.B. 1930. New light on sedimentation and tectonics. Geological Magazine, 67, 77-92.

— \& McCallien, W.J. 1937. Perthshire tectonics: Schiehallion to Glen Lyon. Transactions of the Royal Society of Edinburgh, 59, 79-117.

Barr, D., Roberts, A.M., Highton, A.J., Parson, L.M. \& Harris, A.L. 1985. Structural setting and geochronological significance of the West Highland Granitic Gneiss, a deformed early granite within Proterozoic Moine rocks of N. W. Scotland. Journal of the Geological Society, London, 142, 663-676.

BARROW, G. 1893. On an intrusion of muscovite-biotite gneiss in the southeastern Highlands of Scotland, and its accompanying metamorphism. Quarterly Journal of the Geological Society, London, 49, 330-358.

BLuck, B.J. 1985. The Scottish paratectonic Caledonides. Scottish Journal of Geology, 21, 437-464.

, Dempster, T.J. \& Rogers, G. 1998. Allochthonous metamorphic blocks on the Hebridean passive margin, Scotland. Journal of the Geological Society, London, 154, 921-924.

Bowes, D.R. 1968. The absolute time scale and the subdivision of Precambrian rocks in Scotland. Geologiska Foreningens, Stockholm, Forhandlingar, 90, 175-188.

Brasier, M.D. \& McIlroy, D. 1998. Neonereites uniserialis from $c .600$ Ma year old rocks in western Scotland and the emergence of animals. Journal of the Geological Society, London, 155, 5-12.

Dempster, T.J. 1985. Uplift patterns and orogenic evolution in the Scottish Dalradian. Journal of the Geological Society, London, 142, 111-128.

FAIRCHILD, I.J. \& HARRINGTON, P.M. 1989. A tempestite-stromatolite-evaporite association (late Vendian, East Greenland): a shoreface-lagoon model. Precambrian Research, 43, 101-127.

Fitches, W.R., Pearce, N.J.G., Evans, J.A. \& Muir, R.J. 1996. Provenance of late Proterozoic Dalradian tillite clasts, Inner Hebrides, Scotland. In: Brewer, T.S. (ed.). Precambrian Crustal Evolution in the North Atlantic Region. Geological Society, London, Special Publications, 112, 367-377. 
Friedrich, A.M., Bowring, S.A., Martin, M.W. \& Hodges, K.V. 1999 a. Short-lived continental magmatic arc at Connemara, western Irish Caledonides: implications for the age of the Grampian orogeny. Geology, 27, 27-30.

—, Hodges, K.V., Bowring, S.A. \& Martin, M.W. 1999b. Geochronological constraints on the magmatic, metamorphic, and thermal evolution of the Connemara Caledonides, western Ireland. Journal of the Geological Society, London, 156, 1217-1230.

Friend, C.R.L., Kinny, P.D., Rogers, G., Strachan, R.A. \& Paterson, B.A. 1997. U-Pb zircon geochronological evidence for Neoproterozoic events in the Glenfinnan Group (Moine Supergroup): the formation of the Ardgour granite gneiss, north-west Scotland. Contributions to Mineralogy and Petrology, 128, 101-113.

Gibbons, W. \& Harris, A.L. (eds) 1994. A revised correlation of Precambrian rocks in the British Isles. Geological Society, London, Special Reports, 22.

Gray, D.R. \& Foster, D.A. 1997. Orogenic concepts-application and definition: Lachlan fold belt, eastern Australia. American Journal of Science, 297, 859-891.

Gregory, J.W. 1931. Dalradian geology. Methuen, London.

Gunn, W., Clough, C.T. \& Hill, J.B. 1897. The geology of Cowal. Memoirs of the Geological Survey of Great Britain.

Halliday, A.N., Graham, C.M., Aftalion, M. \& Dymoke, P. 1989. The depositional age of the Dalradian Supergroup: U-Pb and Sm-Nd isotopic studies of the Tayvallich Volcanics, Scotland. Journal of the Geological Society, London, 146, 3-6.

HARris, A.L. 1962. Dalradian geology of the Highland Border near Callander. Bulletin of the Geological Survey of Great Britain, 19, 1-15.

Highton, A.J., Hyslop, E.K. \& Noble, S.R. 1999. U-Pb zircon geochronology of migmatization in the northern Central Highlands: evidence for preCaledonian (Neoproterozoic) tectonometamorphism in the Grampian block, Scotland. Journal of the Geological Society, London, 156, 1195-1203.

Hutchison, A.R. \& Oliver, G.J.H. 1998. Garnet provenance studies, juxtaposition of Laurentian marginal terranes and timing of the Grampian Orogeny in Scotland. Journal of the Geological Society, London, 155, 541-550.

Kinny, P.D., Friend, C.R.L., Strachan, R.A., Watt, G.R. \& Burns, I.M. 1999. U-Pb geochronology of regional migmatites in East Sutherland, Scotland: evidence for crustal melting during the Caledonian orogeny. Journal of the Geological Society, London, 156, 1143-1152.

LAmbert, R.STJ. 1969. Isotope studies relating to the Pre-Cambrian history of the Moinian of Scotland. Proceedings of the Geological Society of London, 1652, 243-245.

— M MeKerrow, W.S. 1976. The Grampian Orogeny. Scottish Journal of Geology, 12, 271-292.

Lindsay, N.G., Haselock, P.J. \& Harris, A.L. 1989. The extent of Grampian orogenic activity in the Scottish Highlands. Journal of the Geological Society, London, 146, 733-735.

Millar, I.L. 1999. Neoproterozoic extensional basic magmatism associated with the West Highland granite gneiss in the Moine Supergroup of NW Scotland. Journal of the Geological Society, London, 156, 1153-1162.

Molyneux, S.G. 1998. An upper Daladian microfossil reassessed. Journal of the Geological Society, London, 155, 741-743.

Noble, S.R., Hyslop, E.K. \& Highton, A.J. 1996. High-precision U-Pb monazite geochronology of the $c$. $806 \mathrm{Ma}$ Grampian Shear Zone and the implications for the evolution of the Central Highlands of Scotland. Journal of the Geological Society, London, 153, 511-514.

Peach, B.N., Horne, J., Gunn, W., Clough, C.T. \& Hinxman, L.W. 1907. The geological structure of the Northwest Highlands of Scotland. Memoirs of the Geological Survey of Great Britain.

Phillips, E.R., Highton, A.J., Hyslop, E.K. \& Smith, M. 1999. The timing and $P-T$ conditions of regional metamorphism in the Central Highlands, Scotland. Journal of the Geological Society, London, 156, 1183-1194.

Piasecki, M.A.J. 1980. New light on the Moine rocks of the Central Highlands. Journal of the Geological Society, London, 137, 41-59.

\& van Breemen, O. 1983. Field and isotopic evidence for a c. $750 \mathrm{Ma}$ tectonothermal event in Moine rocks in the Central Highland region of the Scottish Caledonides. Transactions of the Royal Society of Edinburgh: Earth Sciences, 73, 119-134.
Pidgeon, R.T. \& Compston, W. 1992. A SHRIMP ion microprobe study of inherited and magmatic zircons from four Scottish Caledonian granites. Transactions of the Royal Society of Edinburgh: Earth Sciences, 83, $473-483$.

Ramsay, J.G. 1957. Superimposed folding at Loch Monar, Inverness-shire and Ross-shire. Quarterly Journal of the Geological Society of London, 113, 271-308.

Roberts, D., Gorokhov, I.M., Siedlecka, A., Melnikov, N.N., Turchenko, T.L., Konstantinova, G.V., Kutyavin, E.P. \& Sochava, A.V. 1997. $\mathrm{Rb}-\mathrm{Sr}$ dating of illite fractions from Neoproterozoic shales on Varanger Peninsula, North Norway. Norges geologiske undersøkelse, 433, 24-25.

Robertson, S. \& Smith, M. 1999. The significance of the Geal Charn-Ossian Steep Belt in basin development in the Central Scottish Highlands. Journal of the Geological Society, London, 156, 1175-1182.

Rogers, G., Dempster, T.J., Bluck, B.J. \& Tanner, P.W.G. 1989. A high precision $\mathrm{U}-\mathrm{Pb}$ age for the Ben Vuirich granite: implications for the evolution of the Scottish Dalradian Supergroup. Journal of the Geological Society, London, 146, 789-798.

—, Hyslop, E.K., Strachan, R.A., Paterson, B.A. \& Holdsworth, R.E. 1998. The structural setting and U-Pb geochronology of Knoydartian pegmatites in W Inverness-shire: evidence for Neoproterozoic tectonothermal events in the Moine of NW Scotland. Journal of the Geological Society, London, 155, 685-696.

—, Paterson, B.A., Dempster, T.J. \& Redwood, S.D. 1994. U-Pb geochronology of the 'Newer' Gabbros, NE Grampians (abstract). In: Symposium on Caledonian Terrane Relationships in Britain. BGS Keyworth, September 1994.

Sanders, I.S., van Calsteren, P.W.C. \& Hawkesworth, C.J. 1984. A Grenville $\mathrm{Sm}-\mathrm{Nd}$ age for the Glenelg eclogite in northwest Scotland. Nature, 312, 439-440.

SHACKLETON, R.M. 1958. Downward-facing structures of the Highland Border. Quarterly Journal of the Geological Society of London, 113 (for 1957), 361-392.

Smith, M., Robertson, S. \& Rollin, K.E. 1999. Rift basin architecture and stratigraphical implications for basement-cover relationships in the Neoproterozoic Grampian Group of the Scottish Caledonides. Journal of the Geological Society, London, 156, 1163-1173.

SOPER, N.J. \& ENGLAND, R.W. 1995. Vendian and Riphean rifting in NW Scotland. Journal of the Geological Society, London, 152, 11-14.

\& HARRIS, A.L. 1997. Proterozoic orogeny questioned: a view from Scottish Highland Field Workshops, 1995-1996. Scottish Journal of Geology, 33, $187-190$.

- — \& Strachan, R.A. 1998. Tectonostratigraphy of the Moine Supergroup: a synthesis. Journal of the Geological Society, London, 155, 13-24.

, Ryan, P.D. \& Dewey, J.F. 1999. Age of the Grampian orogeny in Scotland and Ireland. Journal of the Geological Society, London, 156, 1231-1236.

TANNER, P.W.G. 1995. New evidence that the Lower Cambrian Leny Limestone at Callander, Perthshire, belongs to the Dalradian Supergroup, and a reassessment of the 'exotic' status of the Highland Border Complex. Geological Magazine, 132, 473-483.

— \& LeSLIE, A.G. 1994. A pre-D2 age for the 590 Ma Ben Vuirich Granite in the Dalradian of Scotland. Journal of the Geological Society, London, 151, 209-212.

— \& Pringle, M.S. 1999. Testing for the presence of a terrane boundary within Neoproterozoic (Dalradian) to Cambrian siliceous turbidites at Callander, Perthshire, Scotland. Journal of the Geological Society, London, 156, 1205-1216.

_ Dempster, T.J. \& Rogers, G. 1997. New constraints upon the structural and isotopic age of the Oughterard Granite, and on the timing of events in the Dalradian rocks of Connemara, western Ireland. Geological Journal, 32, $247-263$.

Temperley, S. \& Windey, B.F. 1997. Grenvillian extensional tectonics in northwest Scotland. Geology, 25, 53-56.

Vance, D., Strachan, R.A. \& Jones, K.A. 1998. Extensional versus compressional settings for metamorphism: Garnet chronometry and pressuretemperature-time histories in the Moine Supergroup, northwest Scotland. Geology, 26, 927-930. 